\section{Strengthening Internationalism in U.S. Higher Education}

\section{Barbara B. Burn}

Barbara B. Burn is associate provost for International Programs at the University of Massachusetts-Amherst. Address: Box 33280, University of Massachusetts, Amherst MA 01003. FAX: (413) 545-1201.

A s president of the Association of International Education Administrators (AIEA) 1994-95, I appointed what I called a national Agenda Task Force to consider and recommend on what kind of national effort would be needed to strengthen international education in American higher education. The AIEA is an association of professional individuals engaged in the administration of international education. At our first meeting, the task force agreed that a national priority should be the encouragement of research and data collection on how most effectively to internationalize colleges and universities in the U.S. Only two months after that meeting, the U.S. Department of Education agreed to provide a small grant to AIEA to help support a national workshop convened to "recommend on the research needed to guide and support the internationalization of higher education, and the appropriate role of the federal government in this area." Such an undertaking fitted well with the growing emphasis in the federal government on identifying the impacts and outcomes of various programs in order to better justify federal funding of them.

\section{A national priority should be the encour- agement of research and data collec- tion on how most effectively to internationalize colleges and universi- ties in the U.S.}

Close to forty experienced scholars and administrators convened in Washington D.C. August 10-11, 1995 to address this challenge. They included directors of Title VI international and area studies programs, foreign language specialists, directors of international programs offices at a range of universities, representatives of foundations and learned societies such as the American Council of Learned Societies, the Social Science Research Council, and the director and other staff from the Center for International Education, U.S. Department of education. The report and recommendations of the AIEA Working Group were published by AIEA in January 1996 in a publication entitled $A$
Research Agenda for the Internationalization of Higher Education in the United States..

The AIEA Working Group report and recommendations are directly pertinent to university faculty, administrators, and students committed to international education and concerned to make the case for funding it, whether by the U.S. government, universities, foundations, or other organizations. As a few examples, the report urges that much more research be carried out on the following:

- What is the contribution of area/international centers, funded by Title VI, to the development of international curricula at K-12 levels in schools?

- What is the contribution of the Fulbright-Hays

Group Projects Abroad and Seminars Abroad Projects to international education in K-12 and community college projects?

- Does the experience of U.S. study abroad students contribute to internationalization of their colleges/ universities and in what ways?

- What components of undergraduate international education are valued in the market place?

- What effects, educationally, culturally, and/or economically, have a given university's faculty exchanges had on their surrounding communities and state?

- Review and analyze the types of linkages between U.S. and foreign institutions to identify which are most effective in strengthening the international component in American education.

The discussions of the AIEA Working Group framed a wide range of critically important questions, of which the foregoing are only a sampling. Based on these questions and the research suggestions rooted in them, AIEA proposes a Research Agenda which, in the words of the report, "if pursued successfully over the years ahead, would make national and institutional efforts to internationalize higher education more effective."

The November 1994 national election in the U.S. and subsequent developments in national politics have already reduced federal support for international education in U.S. colleges and universities and threaten greater reductions in the futures. This development and the political climate in the country make the report and recommendations of the AIEA Working Group extremely timely. It is hoped that the report and recommendations will stimulate the research and inquiry needed to strengthen the case for international education and the crucial role of the federal government in supporting it. 